\title{
Badania porównawcze zużycia strumieniowo-ściernego wybranych materiałów
}

\section{Comparative tests of stream abrasiveness of selected materials}

\section{Streszczenie}

Zagadnienia odporności na zużycie materiałów stosowanych w budowie maszyn i urządzeń odgrywają istotną rolę. Głównym celem prezentowanych badań było porównanie zużycia wybranych materiałów w warunkach oddziaływania strumienia ściernego na ich powierzchnię. Do badań wytypowano następujące stale: X120Mn12, Hardox Extreme, S355J2. Badania zużycia przeprowadzono na stanowisku zbudowanym na bazie przemysłowego urządzenia do obróbki strumieniowo-ściernej. Jako ścierniwo użyto śrutu metalowego WGH 40. Badania stanowią fragment prac związanych z modyfikacją powierzchni materiałów, a przedstawione wyniki stanowią punkt odniesienia dla badań zużycia warstw napawanych.

Słowa kluczowe: zużycie; ścieranie; tribologia

\section{Abstract}

Problems of wear resistance of materials used in the construction of machines and devices are very important. The main aim of the presented research was to compare the consumption of selected materials under the conditions of abrasive stream activity on their surface. The following steels were selected for the tests: X120Mn12, Hardox Extreme, S355J2. Wear tests were carried out on a stand constructed on the basis of an industrial device for abrasive blasting. WGH 40 metal shot was used as the abrasive. The research is part of the work related to the modification of the surface of the materials, and the presented results are a reference point for the study of wear of the hardfacing layers.

Keywords: wear; abrasion; tribology

\section{Wstęp}

Procesy zużycia odgrywają znaczącą rolę w eksploatacji maszyn i urządzeń. Przyjmuje się [1,2], że w warunkach przemysłowych udział poszczególnych procesów zużycia wynosi ok.: $50 \%$ - ścieranie, $15 \%$ - adhezja, $8 \%$ - erozja, $8 \%$ - zacieranie i 19\% - inne (m.in. fretting, korozja). Zapewnienie częściom maszyn i urządzeń wysokiej odporności na zużycie wydłuża okres ich eksploatacji i przynosi wymierne korzyści ekonomiczne.

Ścieranie można zdefiniować, jako niepożądaną zmianę powierzchni elementu maszyny (materiału), powstałą wskutek oddzielenia się w sposób mechaniczny od powierzchni niewielkich cząsteczek. Do pierwszych symptomów wskazujących na możliwość pojawienia się zużycia ściernego możemy zaliczyć uszkodzenia powierzchni takie jak odkształcenia plastyczne, rysy, pęknięcia [3].

Do podstawowych grup czynników warunkujących wystąpienie zużycia ściernego zaliczamy [3]:

- oddziaływanie materiału ścieranego,

- oddziaływanie materiału ścierającego,

- oddziaływanie substancji pośrednich,

- wpływ szybkości ruchu,

- wpływ obciążenia.
W większości przypadków (w szczególności w górnictwie i przemyśle przeróbczym surowców mineralnych) mamy do czynienia z zużyciem ściernym wynikającym z występowania w miejscu tarcia cząstek ścierniwa, mogącego występować zarówno w postaci luźnej, jak i utwierdzonej. W literaturze wyróżnia się trzy podstawowe mechanizmy zużycia ściernego [4]:

- rysowanie lub bruzdowanie materiałem ściernym działającym pod małym obciążeniem (np. rynny zsypowe materiałów sypkich),

- mikroskrawanie materiałem ściernym działającym pod dużym obciążeniem (młyny kulowe, zęby kół zębatych, mieszarki itp.),

- żłobienie dużymi cząsteczkami działającymi pod dużym obciążeniem (czerpaki koparek, walce kruszarek skał itp.).

Do dominujących należą bruzdowanie i mikroskrawanie

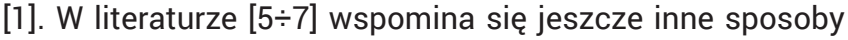
niszczenia materiałów podczas ścierania. Należą do nich erozja i ścieranie zmęczeniowe.

W ustabilizowanych warunkach eksploatacji wielkość zużycia zależy w znacznej mierze od właściwości mechanicznych oddziaływujących na siebie materiałów takich jak twardość

Dr inż. Jarosław Grześ, dr inż. Jerzy Jakubowski - Politechnika Warszawska.

Autor korespondencyjny/Corresponding author: jgrzes@wip.pw.edu.pl 
czy zdolność do odkształceń plastycznych, wyrażana najczęściej przez wydłużenie. Znaczącą rolę odgrywa również kąt, pod jakim cząstki ścierniwa padają na powierzchnię elementu. Zjawisko opisuje teoria Bittera, w dużej mierze potwierdzona doświadczalnie, bazująca na mechanice ciała stałego i uwzględniająca zarówno teorię sprężystości, jak i plastyczności $[3,6]$. W przypadku oddziaływania na powierzchnię elementu strumienia ściernego zużycie ulega zwiększeniu również pod wpływem wzrostu prędkości cząstek, stanowiących ścierniwo $[7,8]$. Pod wpływem dużej prędkości cząstek może wystąpić pękanie i wykruszanie się materiału, co dodatkowo intensyfikuje zużycie, zwłaszcza w przypadku materiałów twardych i kruchych.

Badając odporność na zużycie i określając wpływ poszczególnych czynników na jej wartość, należy uwzględnić charakter strumienia ściernego, jego skład oraz parametry. W badaniach porównawczych powinno stosować się takie same warunki przeprowadzenia prób. Strumień ścierny powinien być odpowiednio ukształtowany pod względem geometrycznym, kinematycznym i dynamicznym. Jako materiał tworzący strumień można zastosować materiały używane w obróbce strumieniowo-ściernej np. za pomocą oczyszczarek wirnikowych, stosowanych m.in. do oczyszczania powierzchni odlewów $[7,8]$.

\section{Przedmiot i metodyka badań}

Celem przeprowadzonych badań było określenie zużycia materiałów podstawowych, stanowiących punkt odniesienia dla zaplanowanych w dalszym etapie badań zużycia warstw napawanych.

Do badań wytypowano trzy materiały:

a) X120Mn12 (1.3401) - stal wysokomanganowa trudnościeralna o strukturze austenitycznej (stal Hadfielda), charakteryzująca się wysoką zawartością węgla i manganu, jedną z cech charakterystycznych tej stali jest utwardzanie (umacnianie) się jej powierzchni podczas ścierania i zgniotu (ze względu na obecność w strukturze wielu kierunków łatwego poślizgu i zachodzące rozdrobnienie ziarna oraz częściową przemianę martenzytyczną), cechuje ją również dobra ciągliwość, zdolność do przenoszenia obciążeń dynamicznych oraz odporność na uderzenia i wysoka twardość w stanie przesyconym, jest materiałem trudnoobrabialnym;

b) Hardox Extreme (oznaczany dalej jako EX_Hardox) - stal należąca do rodziny stali Hardox, o najwyższej wśród nich twardości i odporności na ścieranie, posiadająca rozdrobnione ziarno i strukturę martenzytyczną;

c) S355J2 (1.0562) - stal konstrukcyjna, spawalna, stosowana na konstrukcje stalowe, dostarczana zwykle w stanie uspokojonym.

Podstawową charakterystykę wymienionych materiałów przedstawiono w tablicy I.

Badania przeprowadzono na stanowisku opartym o przemysłowe urządzenie do obróbki strumieniowo-ściernej, zainstalowanym w laboratorium Zakładu Inżynierii Spajania ITW PW. Widok stanowiska przedstawiono na rysunku 1.

Komorę roboczą wyposażono w dwa otwory dostępowe, zabezpieczone rękawicami gumowymi oraz w wyłącznik bezpieczeństwa, wyłączający proces lub uniemożliwiający jego rozpoczęcie w przypadku otwarcia drzwi komory. Ponadto w komorze znajduje się zamocowana lanca pneumatyczna z wymienną końcówką (dyszą) oraz uchwyt do mocowania próbek, wyposażony w skokową regulację kąta ich ustawienia względem osi strumienia ściernego. Zbiornik z układem podającym został wyposażony w zawór umożliwiający regulację strumienia (ciśnienia) ścierniwa. Zużyte ścierniwo
Tablica I. Skład chemiczny i właściwości mechaniczne materiałów zastosowanych w badaniach ścieralności

Table I. Chemical composition and mechanical properties of materials used in abrasion tests

\begin{tabular}{|c|c|c|}
\hline Materiał & Skład chemiczny [\%] & Inne \\
\hline $\begin{array}{c}\mathrm{X} 120 \mathrm{Mn} 12 \\
\text { (DIN) }\end{array}$ & $\begin{array}{c}\mathrm{C}=1,1 \div 1,3 \\
\mathrm{Mn}=12,0 \div 13,0 \\
\mathrm{Si}=0,3 \div 0,5 \\
\mathrm{P}<0,1 \\
\mathrm{~S}<0,04 \\
\mathrm{C}<1,5 \\
\mathrm{Ni}<1,0\end{array}$ & $\begin{array}{c}\mathrm{R}_{\mathrm{m}}=880 \div 1130 \mathrm{MPa} \\
\mathrm{R}_{\mathrm{e}}=\min .410 \mathrm{MPa} \\
\text { Twardość } 240 \div 340 \mathrm{HB}\end{array}$ \\
\hline EX_Hardox & $\begin{array}{c}\mathrm{C}=\max \cdot 0,47 \\
\mathrm{Mn}=\max \cdot 1,4 \\
\mathrm{Si}=\max \cdot 0,5 \\
\mathrm{P}=\max \cdot 0,015 \\
\mathrm{~S}=\max \cdot 0,010 \\
\mathrm{Cr}=\max \cdot 1,2 \\
\mathrm{Ni}=\max \cdot 2,5 \\
\mathrm{Mo}=\max \cdot 0,8 \\
\mathrm{~B}=\max \cdot 0,005\end{array}$ & $\begin{array}{c}\mathrm{R}_{\mathrm{m}}=1800 \mathrm{MPa} \\
\mathrm{R}_{\mathrm{e}}=\text { b.d. } \\
\text { Twardość } 650 \div 700 \mathrm{HB} \\
\mathrm{CET}=0,55 \\
\mathrm{CEV}=0,66\end{array}$ \\
\hline S355J2 & $\begin{array}{c}\mathrm{C}=\max \cdot 0,2 \\
\mathrm{Mn}=1,0 \div 1,5 \\
\mathrm{Si}=0,2-0,55 \\
\mathrm{P}=\max \cdot 0,04 \\
\mathrm{~S}=\max \cdot 0,04 \\
\mathrm{Cr}=\max \cdot 0,3 \\
\mathrm{Ni}=\max \cdot 0,3 \\
\mathrm{Al}=\max \cdot 0,02 \\
\mathrm{Cu}=\max \cdot 0,03\end{array}$ & $\begin{array}{c}\mathrm{R}_{\mathrm{m}}=490 \div 630 \mathrm{MPa} \\
\mathrm{R}_{\mathrm{e}}=355 \mathrm{MPa} \\
\text { Twardość } 220 \mathrm{HB} \\
\mathrm{CET}=0,39 \\
\mathrm{CEV}=0,45\end{array}$ \\
\hline
\end{tabular}

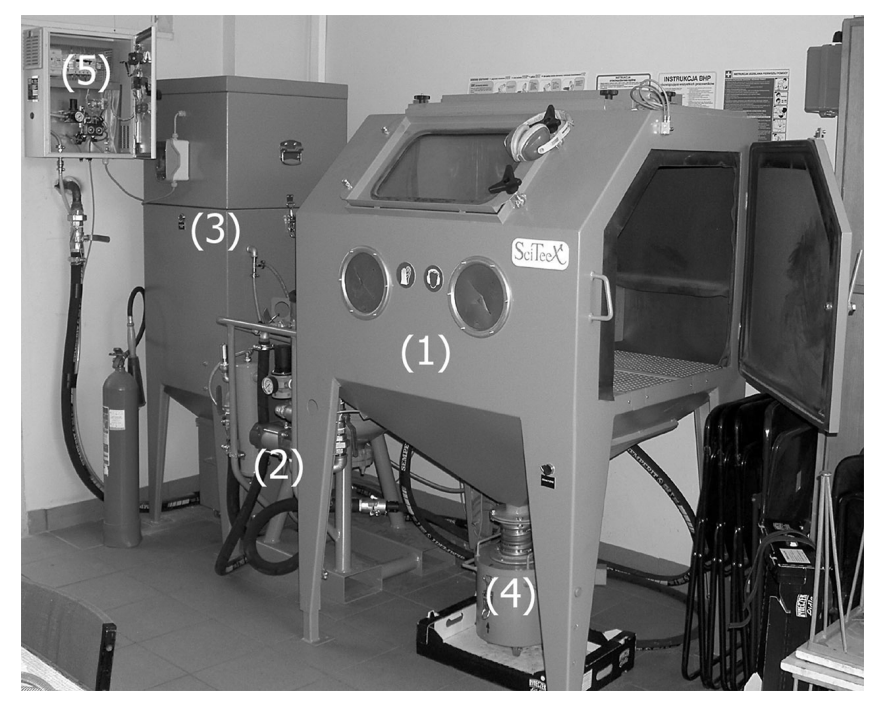

Rys. 1. Stanowisko do badań zużycia strumieniowo-ściernego: komora robocza (1), zbiornik ścierniwa z układem podającym (2), układ filtro-wentylacji komory roboczej (3), zbiornik zużytego ścierniwa (4), układ kontrolno-sterujący (5)

Fig. 1. Stand for testing abrasive blasting: abrasive blast cabinet (1), pressure abrasive blaster (2), dry filter dust collector (3), dust container (4), control system (5)

magazynowane jest w zbiorniku, znajdującym się poniżej komory roboczej i mającego możliwość demontażu w celu usunięcia zużytego ścierniwa. Układ kontrolno-sterujący umożliwia odpowiednie zasilanie, uruchomienie procesu i jego awaryjne przerwanie. Wyposażony został w programowany układ licznika czasu, odmierzającego ustawiony przez operatora czas trwania procesu. 
Badania zużycia strumieniowo-ściernego wymienionych materiałów podstawowych w stanie dostawy przeprowadzono, stosując następujące parametry:

a) rodzaj i granulacja ścierniwa - w badaniach zastosowano śrut stalowy (staliwny) łamany WGH 40 (rys. 2) o twardości 60 $\div 88$ HRC, mający jednorodną mikrostrukturę martenzytyczną i/lub bainityczną, z drobnymi, dobrze rozmieszczonymi węglikami (opis wg firmy P.P.U.H. „KOS”);

b) kąt padania a strumienia ściernego (rys. 3) - na podstawie uprzednio przeprowadzonych analiz i wstępnych prób przyjęto kąty $a=35^{\circ}$ i $a=70^{\circ}$;

c) długość strumienia ściernego - określoną jako odległość między wylotem dyszy a powierzchnią próbki poddanej oddziaływaniu strumienia śrutu, przyjęto na podstawie wstępnych prób $L=75 \mathrm{~mm}$;

d) średnica dyszy - zastosowano dyszę o średnicy d=9 mm (pole przekroju $\mathrm{S}=63,59 \mathrm{~mm}^{2}$ );

e) ciśnienie powietrza doprowadzonego do dyszy - w trakcie badania ciśnienie było odczytywane za pomocą manometru i wynosiło $p=4,3$ bara;

f) wymiary próbki - minimalne wymiary próbek to $50 \times 100 \mathrm{~mm}$;

g) czas trwania oddziaływania strumienia ściernego na badaną powierzchnię - przyjęto 60 s, przy czym dla danego materiału wykonano 3 serie prób; w zależności od serii oddziaływanie strumienia ściernego na badaną powierzchnię następowało w 6-ciu cyklach po $10 \mathrm{~s}$ (seria I), 2-óch cyklach po $30 \mathrm{~s}$ (seria II) i jednym cyklu $60 \mathrm{~s}$ (seria III).

Przed i po przeprowadzeniu próby próbki były ważone. Ważenie wykonywano za pomocą wagi elektronicznej z dokładnością $\Delta=0,001 \mathrm{~g}$. Zużycie strumieniowo-ścierne określono za pomocą ubytku masy próbki (masa zużycia) w danym cyklu/serii i masowej intensywności zużycia. Obserwacje mikroskopowe przeprowadzono na mikroskopie Olympus przy powiększeniach $25 \div 100 x$.

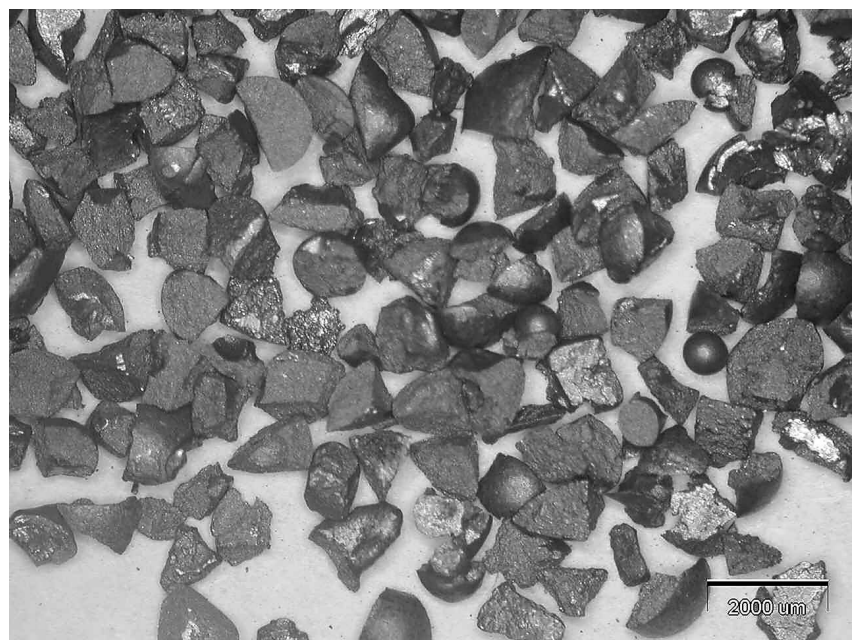

Rys. 2. Śrut stalowy WGH 40 zastosowany w badaniach (pow. 10x) Fig. 2. WGH 40 steel shot used in research (mag. 10x)

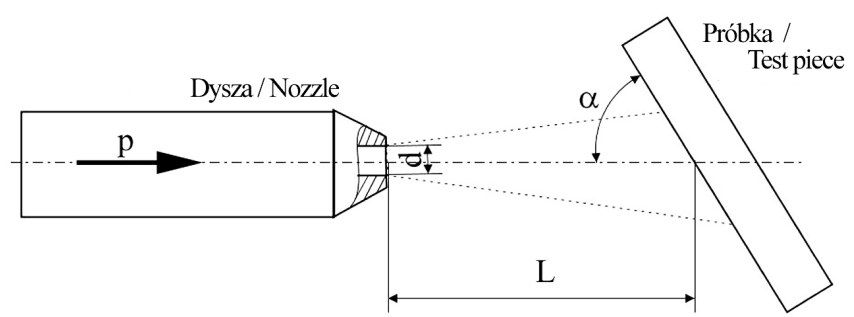

Rys. 3. Podstawowe parametry badania: $a-$ kąt padania strumienia ściernego, d - średnica dyszy, L - długość strumienia ściernego, p - ciśnienie powietrza doprowadzonego do dyszy

Fig. 3. Basic test parameters: $a-$ angle between the direction of the abrasive jet and the test piece flat surface, $d$ - nozzle diameter, $\mathrm{L}$ - distance from the nozzle to the test piece surface, $\mathrm{p}$ - air pressure

\section{Wyniki badań}

Zamieszczono wyniki I serii, jako najbardziej reprezentatywne spośród wykonanych.

W tablicy II zestawiono wyniki dla kąta padania strumienia ściernego $a=35^{\circ}$, a na rysunku 4 przedstawiono je w postaci graficznej. Wyniki dla kąta $a=70^{\circ}$ odpowiednio $w$ tablicy III i na rysunku 5.

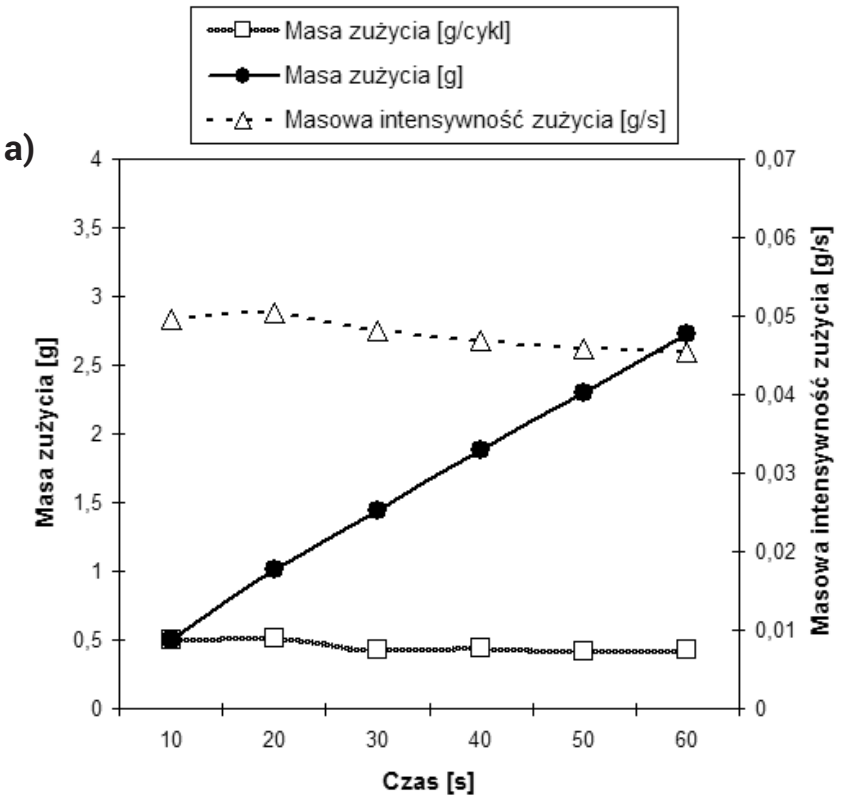

b)

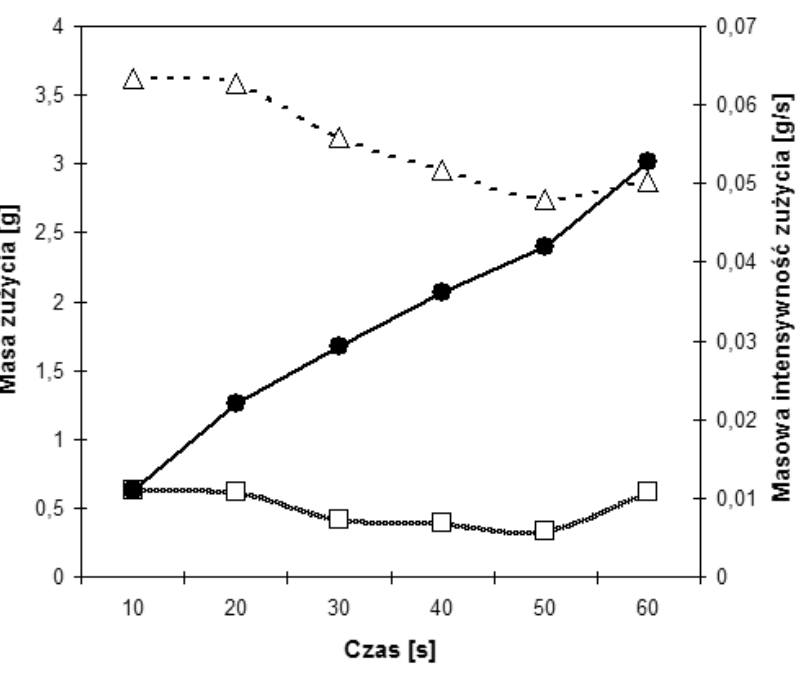

c)

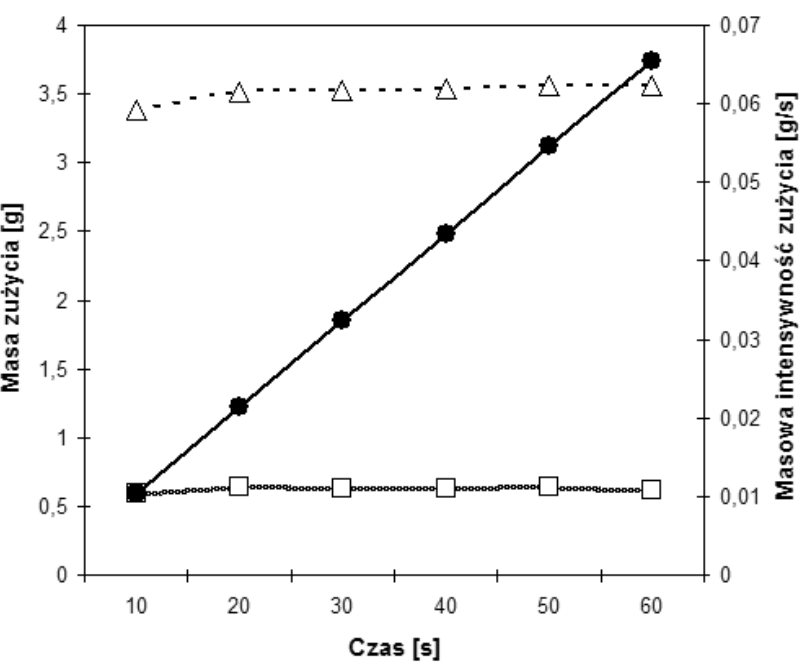

Rys. 4. Wykresy zużycia badanych materiałów dla kąta $\mathrm{a}=35^{\circ}$ a) X120Mn12, b) EX_Hardox, c) S355J2

Fig. 4. Graphs of wear of tested materials for angle $a=35^{\circ}$ a) X120Mn12, b) EX_Hardox, c) S355J2 
Tablica II. Zużycie badanych materiałów dla kąta $\mathrm{a}=35^{\circ}$

Table II. Wear of tested materials for angle $a=35^{\circ}$

\begin{tabular}{|c|c|c|c|c|c|c|c|}
\hline \multirow{2}{*}{\multicolumn{2}{|c|}{$a=35^{\circ}$}} & \multicolumn{6}{|c|}{ Cykl } \\
\hline & & 1 & 2 & 3 & 4 & 5 & 6 \\
\hline \multicolumn{2}{|l|}{ Czas cyklu / czas łączny [s] } & $10 / 10$ & $10 / 20$ & $10 / 30$ & $10 / 40$ & $10 / 50$ & $10 / 60$ \\
\hline \multicolumn{2}{|l|}{ X120Mn12 } & & & & & & \\
\hline Masa próbki [g] & 401,714 & 401,218 & 400,704 & 400,271 & 399,835 & 399,420 & 398,990 \\
\hline Masa zużycia [g/cykl] & - & 0,496 & 0,514 & 0,433 & 0,436 & 0,415 & 0,430 \\
\hline Całkowita masa zużycia [g] & - & 0,496 & 1,010 & 1,443 & 1,879 & 2,294 & 2,724 \\
\hline Masowa intensywność zużycia [g/s] & - & 0,0496 & 0,0505 & 0,0481 & 0,0470 & 0,0459 & 0,0454 \\
\hline \multicolumn{8}{|l|}{ EX_Hardox } \\
\hline Masa próbki [g] & 409,661 & 409,027 & 408,405 & 407,985 & 407,595 & 407,260 & 406,641 \\
\hline Masa zużycia [g/cykl] & - & 0,634 & 0,622 & 0,420 & 0,390 & 0,335 & 0,619 \\
\hline Całkowita masa zużycia [g] & - & 0,634 & 1,256 & 1,676 & 2,066 & 2,401 & 3,020 \\
\hline Masowa intensywność zużycia [g/s] & - & 0,0634 & 0,0628 & 0,0559 & 0,0517 & 0,0480 & 0,0503 \\
\hline \multicolumn{8}{|l|}{ S355J2 } \\
\hline Masa próbki [g] & 591,311 & 590,720 & 590,083 & 589,459 & 588,833 & 588,191 & 587,571 \\
\hline Masa zużycia [g/cykl] & - & 0,591 & 0,637 & 0,624 & 0,626 & 0,642 & 0,620 \\
\hline Całkowita masa zużycia [g] & - & 0,591 & 1,228 & 1,852 & 2,478 & 3,120 & 3,740 \\
\hline
\end{tabular}

Tablica III. Zużycie badanych materiałów dla kąta $\mathrm{a}=70^{\circ}$

Table III. Wear of tested materials for angle $\alpha=70^{\circ}$

\begin{tabular}{|c|c|c|c|c|c|c|c|}
\hline \multirow{2}{*}{\multicolumn{2}{|c|}{$a=70^{\circ}$}} & \multicolumn{6}{|c|}{ Cykl } \\
\hline & & 1 & 2 & 3 & 4 & 5 & 6 \\
\hline \multicolumn{2}{|l|}{ Czas cyklu / czas łączny [s] } & $10 / 10$ & $10 / 20$ & $10 / 30$ & $10 / 40$ & $10 / 50$ & $10 / 60$ \\
\hline \multicolumn{2}{|l|}{ X120Mn12 } & & & & & & \\
\hline Masa próbki [g] & 402,333 & 401,878 & 401,455 & 401,090 & 400,722 & 400,381 & 400,014 \\
\hline Masa zużycia [g/cykl] & - & 0,455 & 0,423 & 0,365 & 0,368 & 0,341 & 0,367 \\
\hline Całkowita masa zużycia [g] & - & 0,455 & 0,878 & 1,243 & 1,611 & 1,952 & 2,319 \\
\hline Masowa intensywność zużycia [g/s] & - & 0,0455 & 0,0439 & 0,0414 & 0,0403 & 0,0390 & 0,0387 \\
\hline \multicolumn{8}{|l|}{ EX_Hardox } \\
\hline Masa próbki [g] & 409,234 & 408,564 & 408,094 & 407,811 & 407,628 & 407,309 & 407,071 \\
\hline Masa zużycia [g/cykl] & - & 0,670 & 0,470 & 0,283 & 0,183 & 0,319 & 0,238 \\
\hline Całkowita masa zużycia [g] & - & 0,670 & 1,140 & 1,423 & 1,606 & 1,925 & 2,163 \\
\hline Masowa intensywność zużycia [g/s] & - & 0,0670 & 0,0570 & 0,0474 & 0,0402 & 0,0385 & 0,0361 \\
\hline \multicolumn{8}{|l|}{ S355J2 } \\
\hline Masa próbki $[\mathrm{g}]$ & 589,594 & 589,136 & 588,688 & 588,171 & 587,687 & 587,210 & 586,757 \\
\hline Masa zużycia [g/cykl] & - & 0,458 & 0,448 & 0,517 & 0,484 & 0,477 & 0,453 \\
\hline Całkowita masa zużycia [g] & - & 0,458 & 0,906 & 1,423 & 1,907 & 2,384 & 2,837 \\
\hline
\end{tabular}




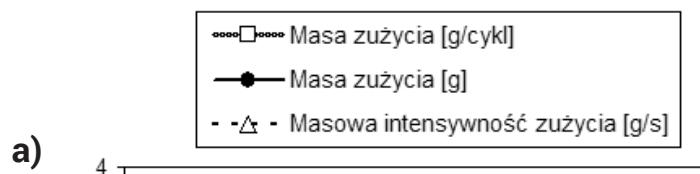

a)

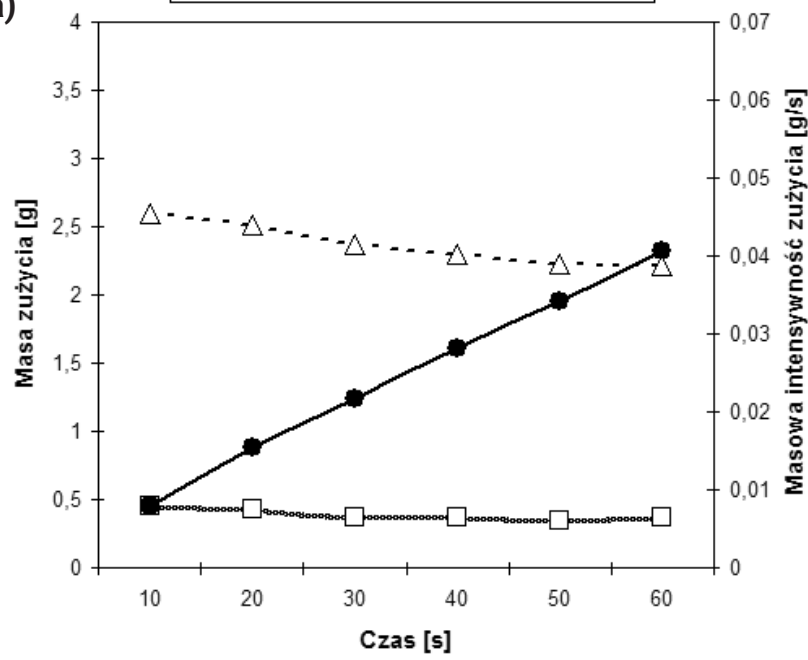

b)

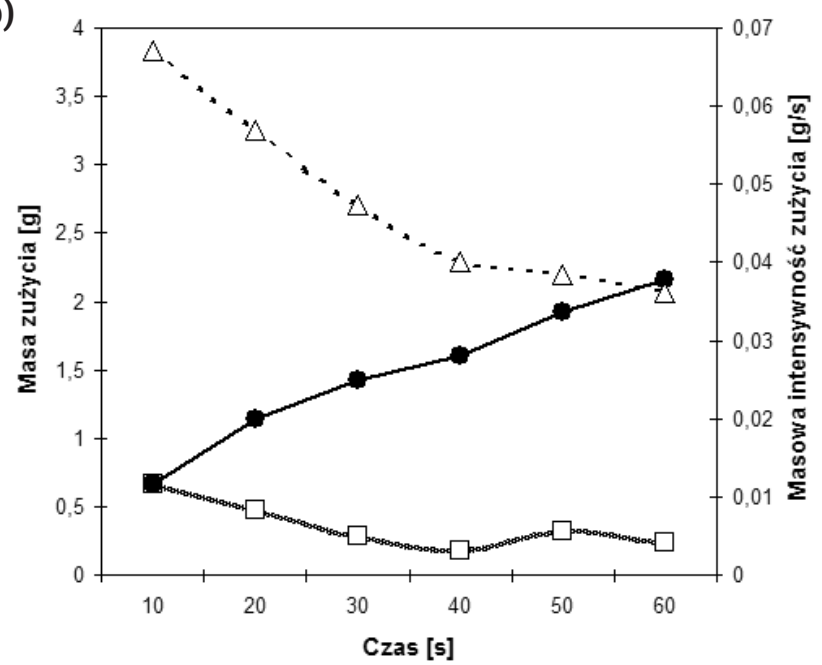

c)

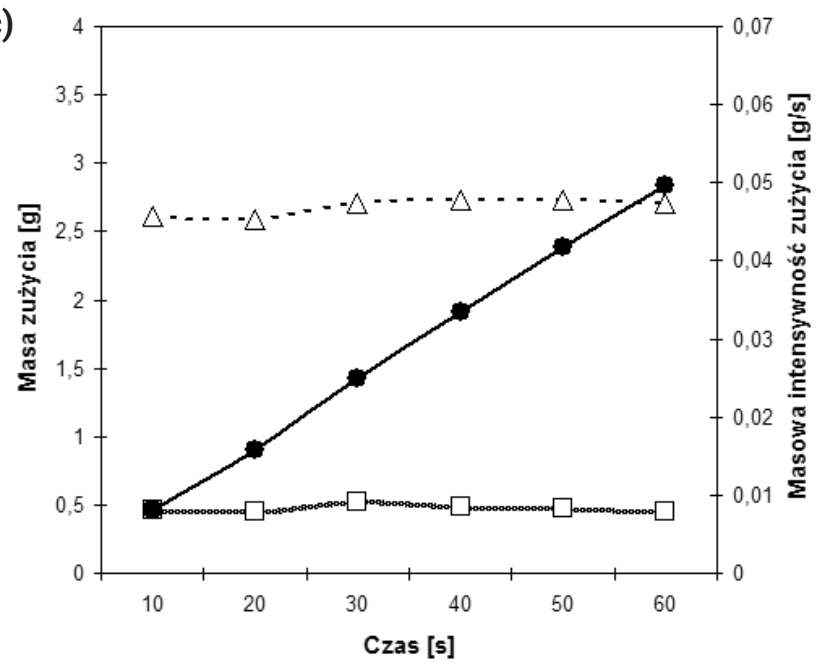

Rys. 5. Wykresy zużycia badanych materiałów dla kąta $\alpha=70^{\circ}$ a) X120Mn12, b) EX_Hardox, c) S355J2

Fig. 5. Graphs of wear of tested materials for angle $a=70^{\circ}$ a) X120Mn12, b) EX_Hardox, c) S355J2

Na rysunku 6 pokazano wygląd powierzchni próbek poddanych oddziaływaniu strumienia śrutu. Wyraźnie rozróżnialne są dwa obszary. Pierwszy (środkowy) związany jest z intensywnym oddziaływaniem głównego nurtu strumienia śrutu na powierzchnię próbki. Drugi (zewnętrzny) powstał w wyniku oddziaływania zewnętrznej części (pobocznicy) strumienia śrutu.
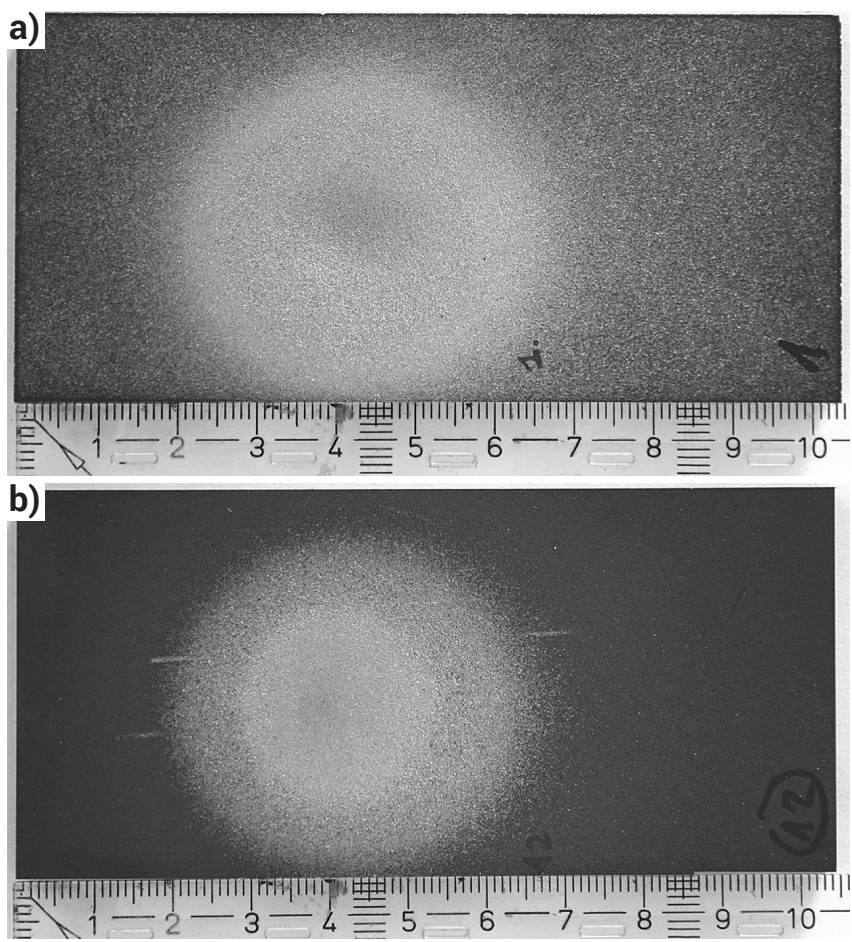

c)

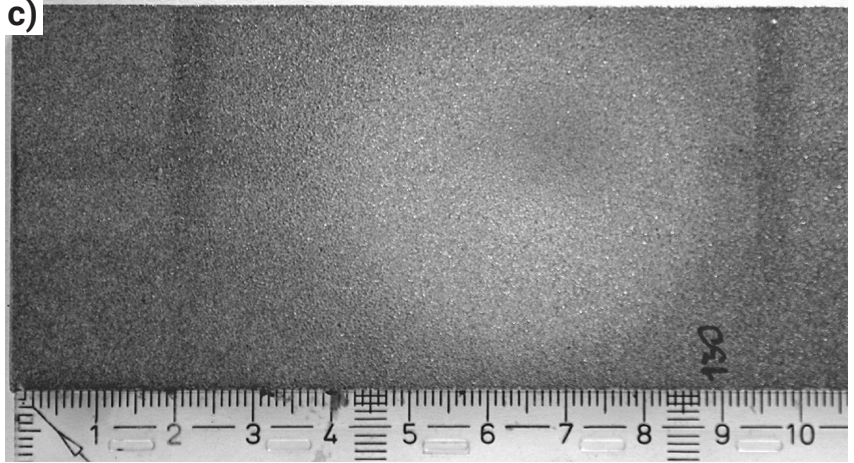

Rys. 6. Obrazy powierzchni próbek poddanych oddziaływaniu strumienia śrutu stalowego (kąt $a=70^{\circ}$ ): a) $\mathrm{X} 120 \mathrm{Mn} 12$, b) EX_Hardox, c) $\$ 355 \mathrm{~J} 2$

Fig. 6. Images of the surface of samples exposed to the stream of steel shot (angle $a=70^{\circ}$ ): a) X120Mn12, b) EX_Hardox, c) S355J2

W ramach oględzin powierzchni próbek podano je obserwacji na mikroskopie optycznym. Wybrane zdjęcia pokazano na rysunku 7 . Wyraźnie widoczny jest efekt oddziaływania strumienia śrutu na powierzchnię próbki, w tym ślady procesu skrawania i odkształceń plastycznych.

\section{Analiza wyników}

Analizując wyniki badań zużycia stwierdzono, że dla wszystkich materiałów wystąpił wzrost masy zużycia w trakcie próby, a masowa intensywność zużycia na ogół zmniejsza się wraz ze wzrostem czasu trwania próby. Taka zależność występuje dla stali X120Mn12 i EX_Hardox. W przypadku stali S355J2 zaobserwowano tendencję zwiększania się wartości masowej intensywności zużycia, przy czym wzrost ten jest stosunkowo niewielki.

W celu bezpośredniego porównania zużycia badanych stali przedstawiono masę zużycia i masową intensywność zużycia w funkcji czasu trwania próby oraz kąta padania a strumienia ściernego na wykresach zbiorczych przedstawionych na rysunkach 8 i 9 . Wykresy sporządzono na podstawie danych pochodzących z pierwszej serii, zawierającej najwięcej punktów pomiarowych.

$\mathrm{Na}$ ich podstawie stwierdzono dla kątów padania $\mathrm{a}=35^{\circ}$ i $\mathrm{a}=70^{\circ}$ podobny charakter odpowiadających sobie krzywych. 

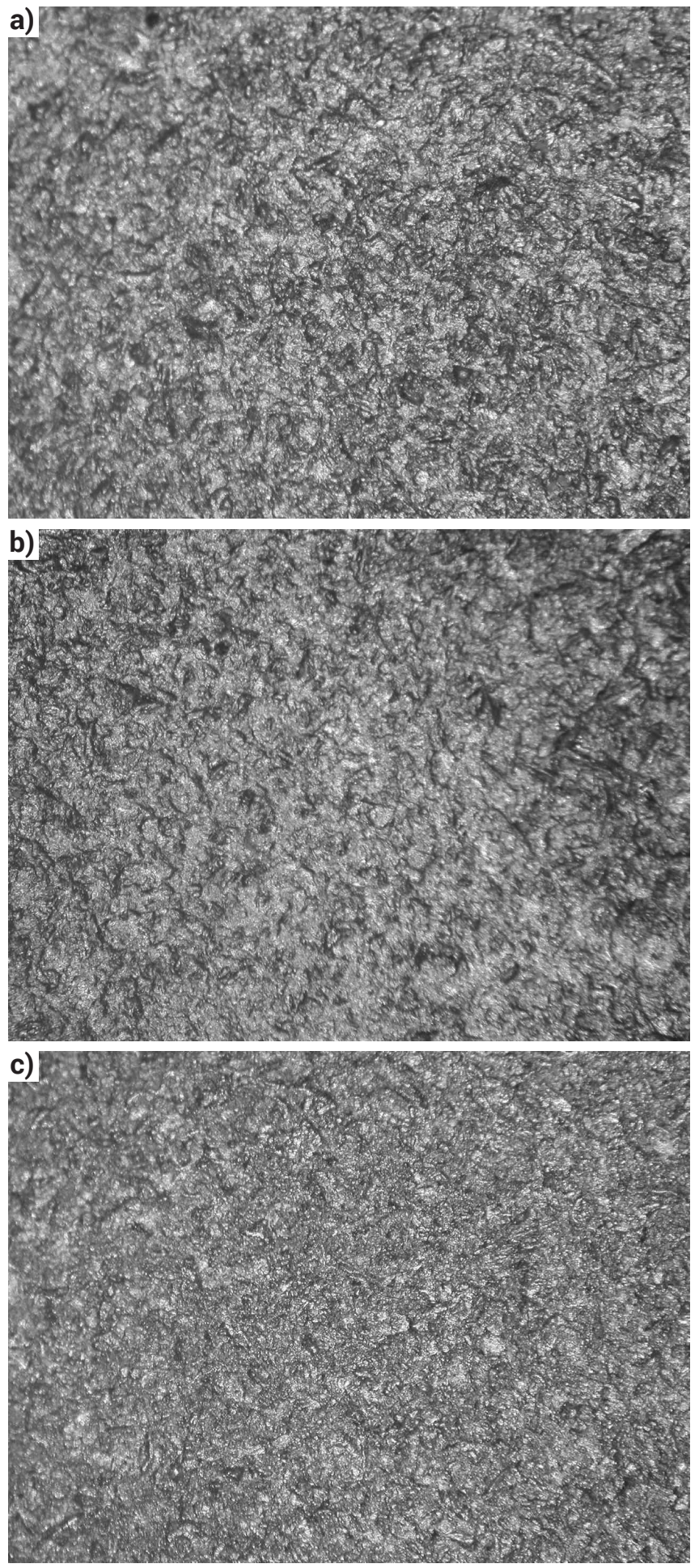

Rys. 7. Morfologia powierzchni eksponowanych, pow. 25x (kąt $a=70^{\circ}$ ) a) X120Mn12, b) EX_Hardox, c) S355J2

Fig. 7. Morphology of exposed surfaces, mag. 25x (angle $a=70^{\circ}$ ) a) X120Mn12, b) EX_Hardox, c) S355J2

Jak należało się spodziewać, największe zużycie wystąpiło dla stali S355J2. W jej przypadku przyrost masy zużycia ma charakter liniowy i występuje stosunkowo stabilne zachowanie się wartości masowej intensywności zużycia w czasie trwania próby. Podobnie w przypadku stali X120Mn12 stwierdzono praktycznie liniowy przyrost masy zużycia, a masowa intensywność zużycia zachowuje się stabilnie, wykazując jednocześnie tendencję spadkową. Największe zmiany zaobserwowano dla stali EX_Hardox. Stwierdzono co prawda niewielkie odstępstwa od liniowego charakteru przyrostu masy zużycia, ale zmiany masowej intensywności zużycia były największe. Stwierdzono również jej największe
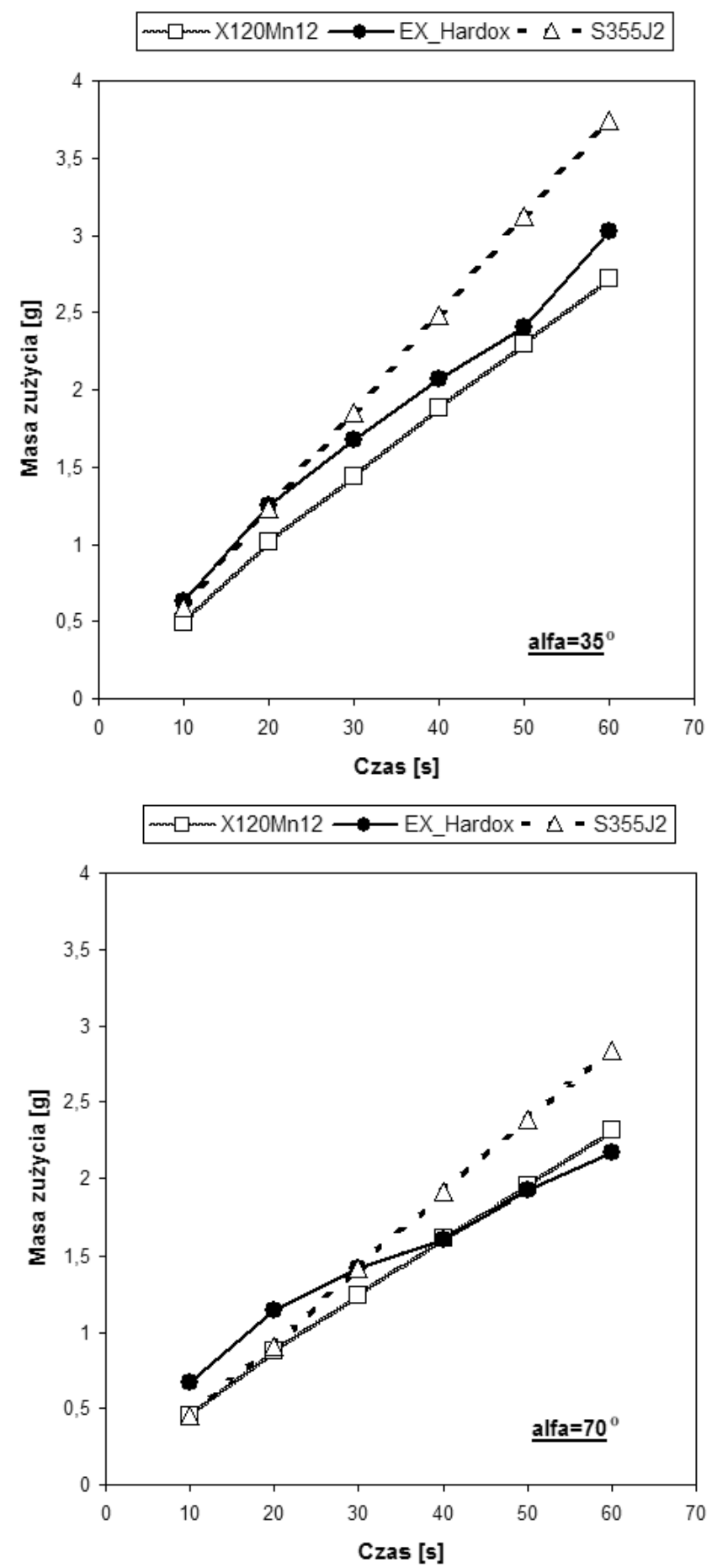

Rys. 8. Masa zużycia dla badanych stali i kątów $a=35^{\circ}$ i $a=70^{\circ}$ Fig. 8. Wear weight for tested steels and angles $a=35^{\circ}$ and $a=70^{\circ}$

zmiany początkowe (dla pierwszego cyklu t=10 s), przy wyraźnej, silnej tendencji spadkowej wraz ze wzrostem czasu oddziaływania strumienia ściernego. Badania potwierdziły wpływ kąta padania a strumienia ściernego na stopień zużycia. Wyższe wartości wielkości opisujących zużycie stwierdzono dla kąta $\mathrm{a}=35^{\circ}$.

Dla zastosowanych parametrów badania (rodzaj śrutu, czas cyklu, kąt padania a) stalą zapewniającą najstabilniejsze zachowanie się $w$ danych warunkach jest stal X120Mn12.

Rysunek 10 pokazuje wpływ kąta padania a strumienia śrutu na wielkość i kształt obszaru stanowiącego ślad po oddziaływaniu śrutu oraz wyniki analizy obrazu, której celem było określenie powierzchni oddziaływania dla kątów padania $a=35^{\circ}$ i $a=70^{\circ}$. Jest wyraźnie widoczne, że zmniejszenie 

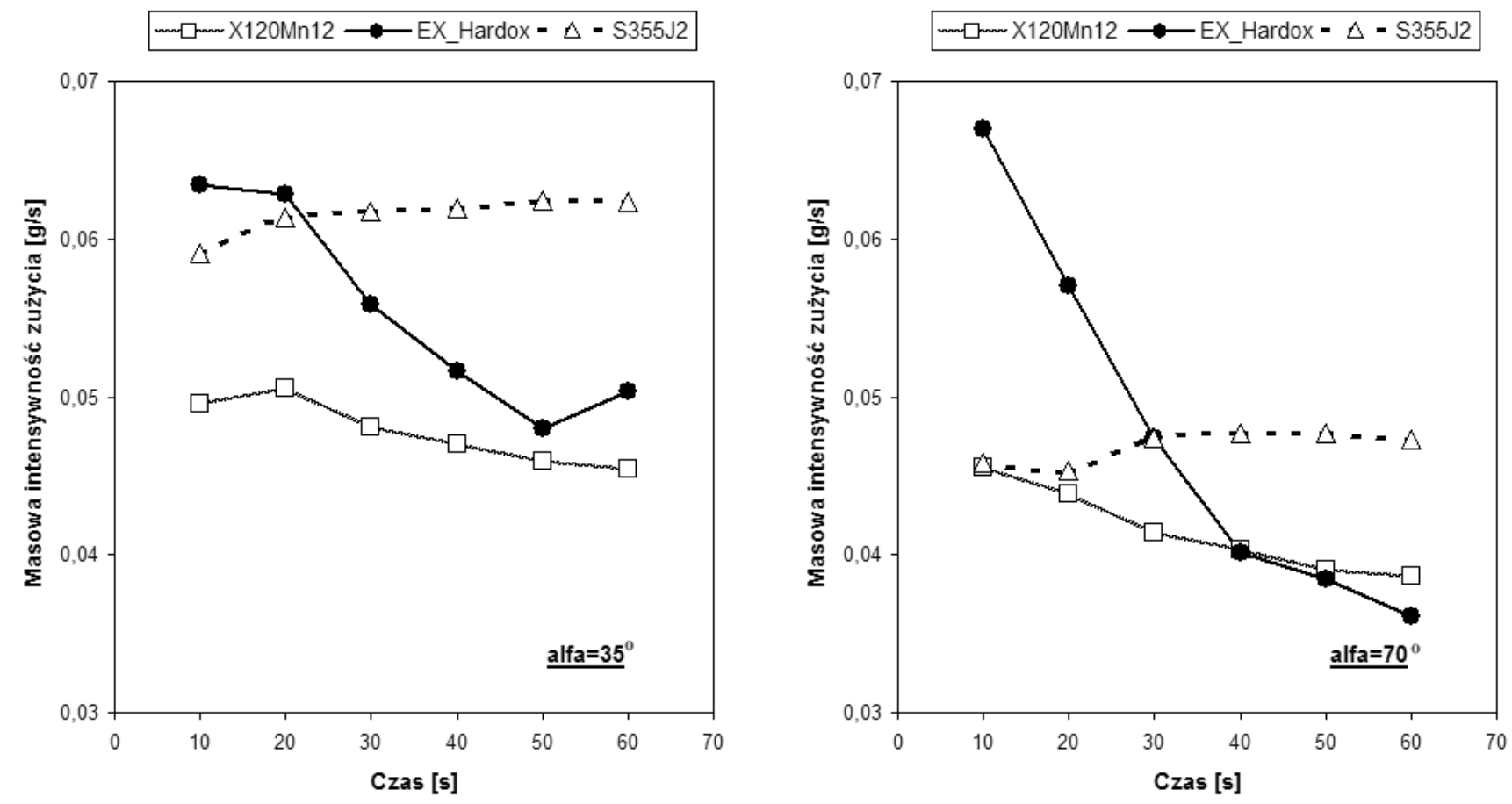

Rys. 9. Masowa intensywność zużycia dla badanych stali i kątów $\mathrm{a}=35^{\circ}$ i $\mathrm{a}=70^{\circ}$

Fig. 9. Mass intensity of wear for the tested steels and angles $a=35^{\circ}$ and $a=70^{\circ}$

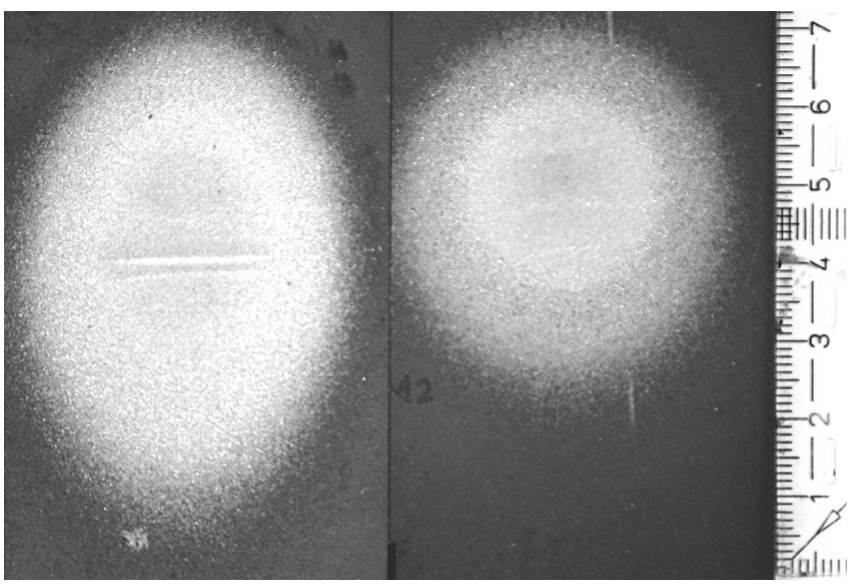

\begin{tabular}{|r|c|c|r|r|}
\hline & Label & Area & Width & Height \\
\hline 1 & EX_HARDOX_1 & 2440,901 & 47,034 & 67,458 \\
\hline 2 & EX_HARDOX_2 & 1772,271 & 44,661 & 49,068 \\
\hline
\end{tabular}

Rys. 10. Porównanie obrazu powierzchni poddanej oddziaływaniu strumienia śrutu stalowego padającego pod kątem $a=35^{\circ}$ (lewa strona) i $a=70^{\circ}$ (prawa strona). Wyniki analizy obrazu (stal EX_Hardox)

Fig. 10. Comparison of the image of the surface exposed to the stream of steel shot falling at an angle $a=35^{\circ}$ (left side) and $a=70^{\circ}$ (right side). Image analysis results (EX_Hardox steel)

kąta podania a strumienia śrutu powoduje zwiększenie się obszaru oddziaływania.

W przypadku kąta padania $\mathrm{a}=35^{\circ}$ obszar oddziaływania jest ok. 1,38 razy większy niż dla kąta padania $a=70^{\circ}$. Należy pamiętać również o tym, że przy zmianie kąta padania a zmieniają się warunki wzajemnego oddziaływania śrutu i powierzchni próbki.

W przypadku stali EX_Hardox zaobserwowano tworzenie się pofałdowań na powierzchni obszaru pierwszego. Pofałdowania występują dla obydwu kątów padania a strumienia ściernego śrutu, z tym, że dla kąta $a=35^{\circ}$ są wyraźniejsze i większe (rys. 11).
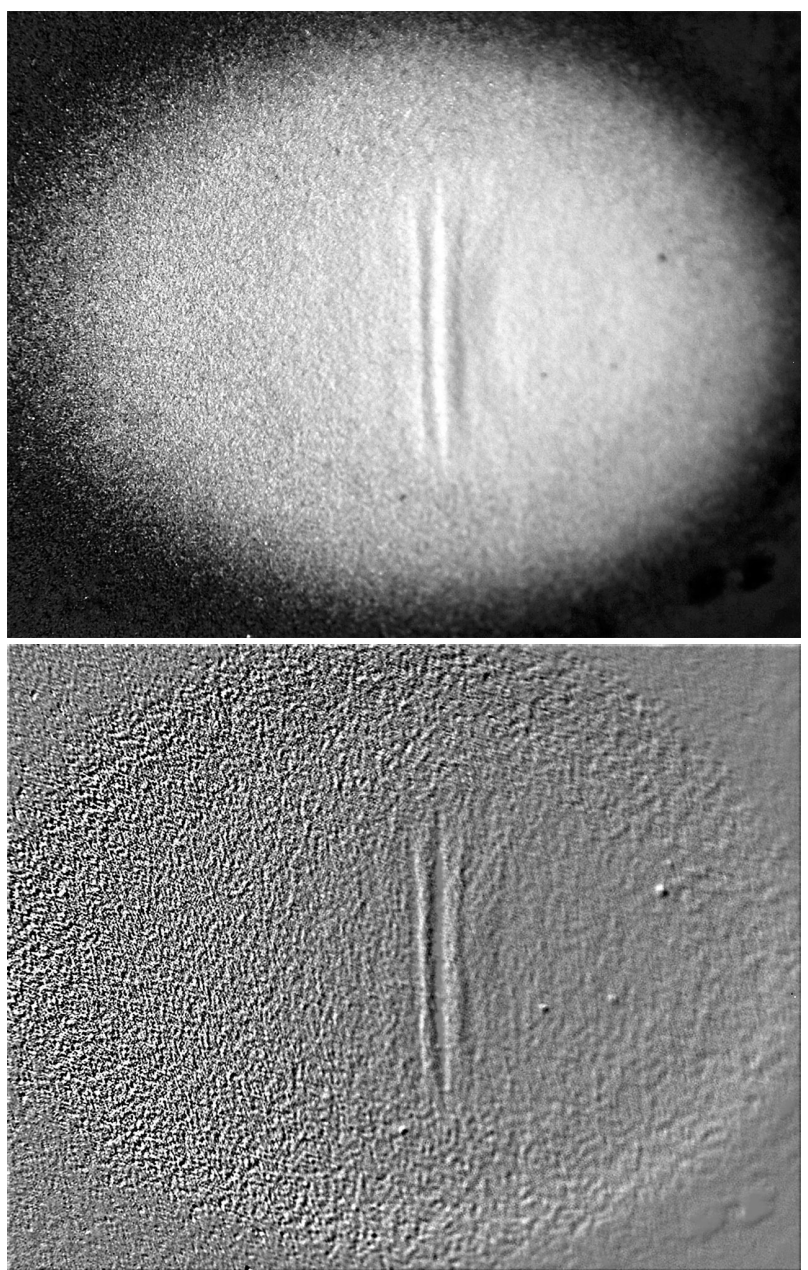

Rys. 11. Charakterystyczny obraz powierzchni stali EX_Hardox poddanej oddziaływaniu strumienia śrutu stalowego (kąt padania $\mathrm{a}=35^{\circ}$, dolny obraz po przetworzeniu cyfrowym)

Fig. 11. A characteristic image of EX_Hardox steel surface exposed to the steel shot stream (angle of falling $a=35^{\circ}$, bottom image after digital processing) 


\section{Podsumowanie}

Przeprowadzone badania umożliwiły określenie stopnia zużycia powierzchni w początkowym okresie oddziaływania strumienia ściernego śrutu stalowego na powierzchnię dla trzech gatunków stali: X120Mn12, EX_Hardox (Hardox Extreme) i S355J2. Jako wielkości charakteryzujące zużycie przyjęto masę zużycia [g] i masową intensywność zużycia [g/s].

Ze względu na złożoność procesu zużycia należy materiały dobierać indywidualnie dla każdego przypadku. Należy również pamiętać, że badania laboratoryjne nie pozwalają w pełni na określenie zachowania się materiału w rzeczywistych warunkach eksploatacji. W przypadku konieczności kompleksowej oceny zużycia pozostaje wykonanie elementów z badanego materiału, zamontowanie ich w maszynie lub urządzeniu i monitorowanie ich zachowania w danych warunkach eksploatacji.

Badania były finansowane z grantu NCBiR/KGHM nr CuBR/1/3NCBR/2014

\section{Literatura}

[1] Hejwowski T., Weroński A.: Problematyka doboru materiałów na elementy pracujące w warunkach zużycia erozyjno-ściernego, Zagadnienia Eksploatacji Maszyn t. 121, nr 1, 2000, s. 30-49.

[2] Liszewski M., Krupicz B., Tarasiuk W.: Wpływ obróbki cieplnej na zużycie erozyjne stali 40Cr4, Tribologia 3/2012.

[3] Profesor Stanisław Jura, twórca teorii i zastosowań przemysłowych diagnostyki oraz zużycia metali i stopów, Archiwum odlewnictwa, wydanie specjalne pod redakcją J. Gawrońskiego, 2004, vol. 4, nr 16.

[4] Gucwa M., Beczkowski R.: Odporność na erozyjne zużycie strumieniowe napoin wykonanych drutem proszkowym samoosłonowym przy kącie padania ścierniwa $60^{\circ}$, Przegląd Spawalnictwa 10/2011.
[5] Modern Tribology Handbook, Ed. Bharat Bhushan, CRC Press, 2001

[6] Bushan B.: Introduction to Tribology. 2nd Edition, John Wiley \& Sons, Ltd, 2013.

7] Rzadkosz S., Staszczak L. Mikrostruktura i właściwości stopów na łopatki rzutowe oczyszczarek strumieniowo-ściernych, IX Konferencja Odlewnicza Technical 2006.

[8] Zyzak P.: Ocena parametrów strumienia śrutu wskaźnikami próby z użyciem płytek kontrolnych. XXXVIII Naukowa Szkoła Obróbki Ściernej, Łódź-Uniejów 09-11-09.2015. 